\title{
Effects of Kinesio Taping on Pain and Quality of Life of Patients with Cervical Myofascial Pain Syndrome: A Randomized Controlled Study
}

\author{
Servikal Miyofasiyal Ağrı Sendromu Olan Hastalarda Kinezyo Bantlamanın Ağrı ve Hayat \\ Kalitesi Üzerine Etkisi: Randomize Kontrollü Bir Çalışma
}

\author{
(D) Sasan Zardoust, (D) Oya Özdemir, (D) Sevilay Karahan*, (D) Pınar Borman \\ Hacettepe University Faculty of Medicine, Department of Physical Medicine and Rehabilitation, Ankara, Turkey \\ * Hacettepe University Faculty of Medicine, Department of Bioistatistics, Ankara, Turkey
}

\section{Abstract}

Objective: A variety of tools are available for myofascial pain syndrome (MPS) treatment; however, it is still one of the most challenging musculoskeletal disorders to treat. This study aimed to determine the effects of kinesio taping (KT) on pain and quality of life in patients with cervical MPS.

Materials and Methods: A total of 55 patients were randomly assigned into therapeutic and sham KT groups. In addition to a home-based exercise program, KT was applied on trapezius muscle at 5-day intervals for 20 days. Pain severity and pressure pain threshold (PPT) were assessed by visual analog scale (VAS) and algometer, respectively. Short form-36 (SF-36) scale was used to determine the patients' healthrelated quality of life. All participants were evaluated before, immediately after, and 1 month after the end of treatment (follow-up visit).

Results: The patient demographic characteristics were found to be similar in both groups. Immediately after the treatment, a statistically significant decrease in VAS and increased PPT and SF-36 scores in both groups were found, with sustained improvement at a follow-up visit. However, no significant difference was determined between the therapeutic and sham KT groups.

Conclusion: KT combined with a home-based exercise program appears to decrease pain severity and improve the quality of life of patients with cervical MPS; however, comparable benefits were also obtained from sham therapy.

Keywords: Kinesio tape, myofascial pain syndrome, neck, quality of life

\section{$\ddot{O z}$}

Amaç: Her ne kadar çeşitli seçenekler olsa da miyofasiyal ağrı sendromu (MFAS) halen tedavisi en uğraştırıcı kas iskelet sistemi sorunlarından biridir. Bu çalışmanın amacı servikal MFAS olan hastalarda kinezyo bantlamanın (KB) ağrı ve hayat kalitesi üzerine etkilerini belirlemektir.

Gereç ve Yöntem: Elli beş hasta terapötik ve sham KB grubuna randomize olarak ayrıldı. Ev egzersiz programının yanı sıra 5 gün aralıklarla 20 gün süreyle hastaların trapezius kasına KB uygulandı. Ağrı şiddeti vizüel analog skala (VAS) ve basınç ağıı eşiği (BAE) algometre ile ölçüldü. Hastaların sağlıkla ilişkili hayat kalitesi belirlemek için Short form-36 (SF-36) ölçeği kullanıldı. Tüm katılımcılar tedavi öncesinde, tedavinin hemen bitiminde ve tedavi bitiminden 1 ay sonra (izlem viziti) değerlendirildi.

Bulgular: Her iki gruptaki hastaların demografik özellikleri birbirine benzer bulundu. Her iki grupta da tedavinin hemen bitiminde istatistiksel olarak anlamlı düzeyde VAS değerlerinde azalma, BAE ve SF-36 skorlarında ise artı̧̧ tespit edilirken bu düzelme izlem vizitinde de devam etmekteydi. Fakat, terapötik ve sham KB grupları arasında anlamlı bir fark saptanmadı.

Sonuç: Her ne kadar ev egzersiz programı ile kombine edilen KB uygulaması servikal MFAS olan hastalarda ağıı şiddetini azaltıp yaşam kalitesini artırıyor gibi görünse de benzer etkiler sham tedavi uygulanan hastalarda da elde edilmiştir.

Anahtar kelimeler: Kinezyo bantlama, miyofasiyal ağrı sendromu, boyun, hayat kalitesi 


\section{Introduction}

Myofascial pain syndrome (MPS) is a common non-inflammatory musculoskeletal disorder presented with regional muscle pain and characterized by hypersensitive nodule called trigger point. The diagnosis of MPS depends on detailed history and thorough physical examination. If necessary, laboratory or imaging tests can be performed for the differential diagnosis of chronic musculoskeletal pain conditions. Trigger point can be easily identified through physical examination within a tight band of the affected muscle, palpation of which may elicit referred pain and local twitch response. Regional pain may be accompained by muscle stiffness, limited range of motion, muscle weakness without atrophy and autonomic signs $(1,2)$. As a consequence of these disabiling symptoms, MPS can cause significant deterioration in many aspects of quality of life (QOL). Hence, in most of the studies corcerning management of MPS, QOL questionnaires were used as an outcome measure to demonstrate the beneficial effects of the treatment (3).

Although its exact etiology is still unclear, several causal factors for the development of MPS including acute muscle overload, trauma, poor posture and psychological stress have been postulated. Thus, single treatment modality usually can not resolve the symptoms completely. The treatment options of MPS include analgesic drugs, local injections, physical therapy modalities, manual therapies, and acupuncture. Eliminating predisposing factors and structured exercise programs are mainstay approaches for optimal management of MPS (4). Recently, kinesio taping (KT) has been introduced as a new therapy for the patients with MPS. This method was developed by Dr. Kenzo Kase in the 1970s and became popular quickly for the management of many musculoskeletal diseases such as sports injuries, shoulder impingement syndrome, low back pain, and plantar fasciitis (5). However, researches conducted for assesing its effects often have shown conflicting results. To the best of our knowledge, there are only very few studies investigating the therapeutic effects of KT on MPS (6-10). The aim of this study was to determine the effects of KT on pain and health-related QOL in patients with an active upper trapezius myofascial trigger point.

\section{Materials and Methods}

Fifty-five patients with the diagnosis of MPS according to the criteria of Travell and Simons, who consecutively admitted to the department of physical medicine and rehabilitation, were participated in this prospective, randomized, single-blinded, sham-controlled study. Patients aged between 18-60 years who have an active trigger point in the upper trapezius muscle with a symptom duration of at least 6 months were included in the study. The exclusion criteria were as follows: fibromyalgia, cervical disc herniation, thoracic outlet syndrome, nerve entrapments of upper extremity, kyphoscoliosis, pregnancy, receiving physical therapy or trigger point injection in the last 3 months, history of neck or shoulder surgery.
Demographic data including age, gender, body weight index, dominant hand, education level, marital status, and occupational physical demand (classified as mild, moderate or severe) were recorded on a standart form. The clinical characteristics such as the area of referred pain and presence of local twitch response were also noted. The study protocol was approved by the Hacettepe University Non-Invasive Clinical Research Ethics Committee (decision no: GO 15/158-08, date: 18.03.2015) and all the participants signed a written informed consent form.

\section{Interventions}

In order to prevent bias, simple randomization was applied. Accordingly, patients were blinded and randomly assigned into therapeutic KT (group 1, n=28) and sham KT (group 2, n=27) groups in a 1:1 allocation ratio. KT (Kinesio ${ }^{\circledR}$ Tex Gold) were applied by a certified KT practitioner, at 5-day intervals for 20 days. The muscle inhibition technique described by Kase was used for group 1 patients (Figure 1). While the patient was in a relaxed sitting position, the anchor was applied at the acromion. After then, the patient was asked to laterally flex his/her neck to the opposite side and rotate his/her head to the same side. The ' $I$ ' strip was attached to the spinous process of C7 vertebra and nuchal line. The KT has no tension at its distal and proximal attachments, whereas the strip was stretched with 15$25 \%$ tension in between these 2 points. For group 2, the same material was placed on upper trapezius muscle without any tension in the neutral position of head and neck. In addition to taping, a home-based program including posture and trapezius stretching exercises was prescribed to all of the participants. The patients were asked to perform two sets of 10 repetitions, twice a day.

\section{Measurement Outcomes}

All subjects were evaluated before treatment (TO), immediately after treatment (T1) and at 1 month after the end of treatment (T2). The severity of pain at rest and during daily activities were assessed by a $10 \mathrm{~cm}$ visual analog scale (VAS) where 0 indicates no pain, 10 indicates the worst pain ever. Pressure pain threshold

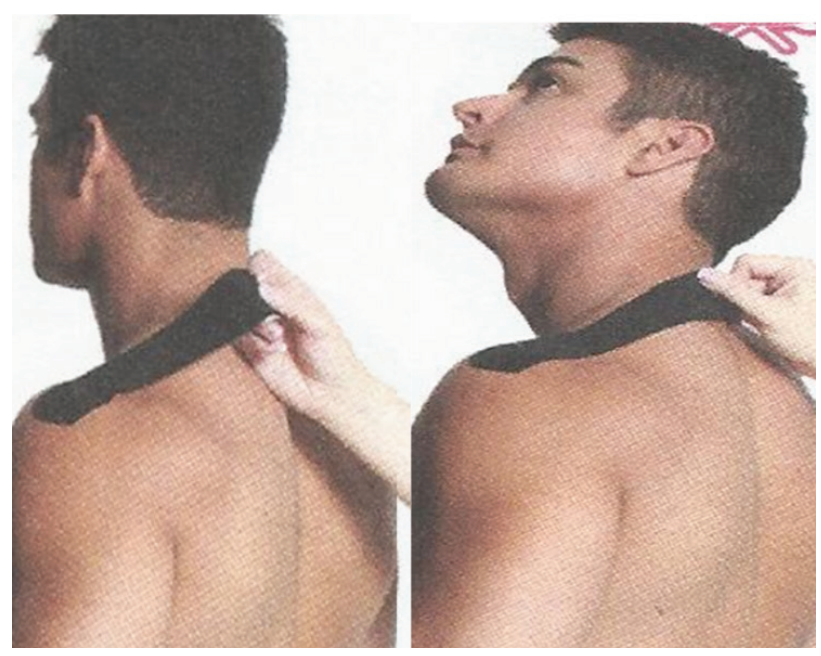

Figure 1. Kinesio tape applied by mucle inhibition tecnique 
(PPT) on the trigger point was detected by a digital algometer (Algometer Commander, JTECH Medical, USA). The algometer has a disc-shaped tip with a surface area of $1 \mathrm{~cm}^{2}$, placed at the trigger point and pressure was increased at a constant rate of 1 $\mathrm{kg} / \mathrm{sec}$. The patients were asked to tell the point at which they perceived pain. The measurement was repeated three times for each particapant and the mean value of these 3 pressure measurements, expressed in terms of $\mathrm{kg} / \mathrm{cm}^{2}$, was recorded.

The Turkish version of Medical Outcomes Study-Short form-36 (SF-36) was used to estimate the patients' health-related QOL. This questionnaire has eight domains including physical functioning, role limitation due to physical problems, role limitation due to emotional problems, bodily pain, social functioning, mental health, vitality, and general health perception. It takes 5 to 10 minutes to answer this self-administered questionnaire. The total score ranges between 0-100, where the higher scores indicates the better health conditions (11).

\section{Statistical Analysis}

Statistical analyses were performed with IBM SPSS for Windows version 21.0 statistical software. Continuous variables were presented as mean \pm standard deviation or median $\left(25^{\text {th }}\right.$ $75^{\text {th }}$ percentile), categorical variables were summarized as frequencies and percentages. Normallity of the continuous variables was verified by Shapiro-Wilk's test. Differences between independent groups according to continuous variables were determined by independent samples t-test or Mann-Whitney $U$ test. Categorical variables were compared by chi-square or Fisher's exact test. Friedman test was used to determine within group differences. Significance value was considered as 0.05 .

\section{Results}

After being randomized, one patient in group 1 and one patient in group 2 dropped out of the study because they didn't attend the follow-up visits regularly. Moreover, one patient in group 1 and one patient in group 2 experienced local allergic reactions and left the study. Finally, 51 patients (50 women, 1 men) with a mean age of $31.2 \pm 10.4$ years (range:18-55) were completed the study. There were no significant difference in the mean values of age and body mass index between each group. Forty-six (90.2\%) patients declaired right side as her/his dominant hand. The distribution of education level, mariatal status and occupational physical demands of the groups were also similar (Table 1).

The median values of symptom duration in group 1 and 2 were 3 (2-7) and 4 (2-5) years, respectively. No statistically significant difference was determined between two groups ( $p=0.894)$. A total of $45(88.2 \%)$ patients -25 of them in group 1- had referred pain. The most common locations were shoulder (55.6\%), followed by neck (31.1\%) and upper back (13.3\%). Local twitch response was positive in 7 patients from each group $(27.5 \%$ of all participants). The area of referred pain $(p=0.120)$ and presence of local twitch response $(p=1.000)$ were similar in the groups.

At baseline visit (T0), the median values of VAS, PPT and SF-36 scores of both groups were found to be similar. Immediately after the treatment ( $\mathrm{T} 1)$, there were statistically significant decrease in VAS and increase in PPT and SF-36 scores in both groups. However, the median values of VAS, PPT and SF-36 scores of each group were comparable at T1 and T2 visits. Just as TO visit, there were no significant difference between two groups in regard of VAS, PPT and SF-36 values at T1 and T2 visits (Table 2).

\section{Table 1. Demographic characteristics of the patients}

\begin{tabular}{|c|c|c|c|}
\hline & Group $1(n=26)$ & Group $2(n=25)$ & p-value \\
\hline Age (years) & $30.1 \pm 10.5$ & $32.5 \pm 10.3$ & 0.413 \\
\hline Body mass index $\left(\mathrm{kg} / \mathrm{m}^{2}\right)$ & $22.7 \pm 3.2$ & $25.2 \pm 4.9$ & 0.096 \\
\hline \multicolumn{4}{|l|}{ Dominant hand } \\
\hline Right & $24(92.3 \%)$ & $22(88 \%)$ & \multirow{2}{*}{0.668} \\
\hline Left & $2(7.7 \%)$ & $3(12 \%)$ & \\
\hline \multicolumn{4}{|l|}{ Educational level } \\
\hline Elemantary & $4(15.4 \%)$ & $5(20 \%)$ & \multirow{3}{*}{0.782} \\
\hline Secondary/high & $3(11.5 \%)$ & $4(16 \%)$ & \\
\hline University & $19(73.1 \%)$ & $16(64 \%)$ & \\
\hline \multicolumn{4}{|l|}{ Mariatal status } \\
\hline Single & $12(46.2 \%)$ & $11(44 \%)$ & \multirow{2}{*}{1.000} \\
\hline Married & $14(53.8 \%)$ & $14(56 \%)$ & \\
\hline \multicolumn{4}{|c|}{ Occupational physical demand } \\
\hline Mild & $15(57.7 \%)$ & $17(68 \%)$ & \multirow{3}{*}{1.000} \\
\hline Moderate & $7(26.9 \%)$ & $5(20 \%)$ & \\
\hline Severe & $4(15.4 \%)$ & $3(12 \%)$ & \\
\hline
\end{tabular}




\section{Discussion}

Despite its widespread use for the treatment of sport injuries and musculoskeletal diseases, there is little data regarding the effects of KT on MPS in the literature. The main effect of KT is elevating the space under skin and soft tissue; so that the space for muscle movement can be enlarged, and the inflammation factors can be reduced by the fascilitation of blood and lymphatic circulation. The therapeutic effects of KT have been also attributed to the gate control theory and proprioseptive biofeedback (12). Shah et al. (13) showed that the patients with active trigger points in the upper trapezius muscle have lower ph values and higher concentrations of inflammatory mediators, neuropeptides, catecholamines, and cytokines within the local milieu of the trigger point than the subjects with latent or absent trigger points. So recirculation through realignment and decompression of the fascia may relieve the symptoms of MPS. Moreover, improving circulation by increasing the space of fascia with KT can remove the heat produced from inflammation, thus a cooling effect may occur. It has been also suggested that reduction of pressure on nociceptors in the skin may also diminish the pain in patients with MPS (12).

In a recent study conducted by Öztürk et al. (8), short and midterm effects of KT on neck pain and upper trapezius muscle strength were examined in patients with MPS. While 20 patients who have active trigger point in their upper trapezius region were treated with KT (group 1), 17 patients received sham therapy (group 2). Kinesio tape was applied twice, with 1 day of rest between applications. Additionally, all patients performed a home-based program including neck muscles stretching and strengthening exercises. In accordance with our study, the participants were evaluated before treatment, immediately after treatment and at 1 month after treatment. It has been found that immediately after treatment there were significant reduction in pain severity and increase in muscle strength, in favour of group 1. However, these improvements continued between post-treatment and follow-up visits only in group 1 . Reduced pain severity in group 2 has been considered to be the results of possible psychological effects of tape application and sensory feedback. Similarly, Ay et al. (9) investigated the effects of KT on pain severity, PPT, cervical range of motion, and disability in cervical MPS patients. Thirty-one patients were treated with $\mathrm{KT}$ and 30 patients with sham KT, applied to levator scapula muscle, 5 times by intervals of 3 days for 15 day. Patients received a home-based exercise program everyday for 2 weeks. After treatment, all parameters showed statistically significant improvements in both groups. However, reduction of pain and increase in PPT and cervical range of motion (flexion and extension) were found to be more pronounced in the treatment group. Unfortunately, no follow-up visit to show the mid or long term effects of KT was included in this study.

To the best of our knowledge, in the literature there are two randomised studies comparing the efficacy of KT with other treatment approaches in patients with MPS $(7,10)$. Azatcam et al. (10) compared the effects of transcutaneous electrical nevre stimulation (TENS) and KT on pain, disability and cervical contralateral lateral flexion. They randomly assigned 69 MPS patients into 3 groups as exercise, TENS with exercise, and KT with exercise groups and reported that combination of TENS or KT with exercise therapy lead to more significant

\section{Table 2. Comparison of the patients' pain intensity and quality of life before and after the treatment}

\begin{tabular}{|c|c|c|c|c|}
\hline & Before treatment (T0) & $\begin{array}{l}\text { Immediately after } \\
\text { treatment (T1) }\end{array}$ & $\begin{array}{l}1 \text { month } \\
\text { after treatment (T2) }\end{array}$ & p-value \\
\hline \multicolumn{5}{|l|}{ VAS-rest } \\
\hline Group 1 & $7.0(5.0-8.3)$ & $4.0(3.0-5.0)$ & $5.0(2.0-5.5)$ & $0.001^{*}$ \\
\hline Group 2 & $7.0(6.0-9.0)$ & $5.0(3.8-7.0)$ & $5.0(3.5-6.8)$ & $0.001 *$ \\
\hline p-value & 0.519 & 0.120 & 0.178 & \\
\hline \multicolumn{5}{|c|}{ VAS-activity } \\
\hline Group 1 & $8.0(6.5-9.0)$ & $5.0(3.5-6.0)$ & $4.5(3.8-6.0)$ & $0.001 *$ \\
\hline Group 2 & $7.0(5.3-8.0)$ & $5.0(3.0-6.0)$ & $5.0(3.0-6.0)$ & $0.001 *$ \\
\hline p-value & 0.140 & 0.975 & 0.783 & \\
\hline \multicolumn{5}{|l|}{ PPT } \\
\hline Group 1 & $45.5(35.8-53.3)$ & $51.0(44.0-66.3)$ & $51.5(42.8-67.3)$ & $0.001^{*}$ \\
\hline Group 2 & $43.0(37.0-51.0)$ & $44.0(40.0-53.5)$ & $45.0(39.5-55.0)$ & $0.001^{*}$ \\
\hline p-value & 0.254 & 0.051 & 0.052 & \\
\hline \multicolumn{5}{|l|}{ SF-36 } \\
\hline Group 1 & $68.8(37.5-87.5)$ & $75.0(50.0-87.5)$ & $75.0(50.0-87.5)$ & $0.001^{*}$ \\
\hline Group 2 & $62.5(37.5-81.3)$ & $62.5(50.0-87.5)$ & $75.0(50.0-87.5)$ & $0.001^{*}$ \\
\hline p-value & 0.127 & 0.065 & 0.90 & \\
\hline
\end{tabular}


improvement than exercise alone. KT was found to be more effective than TENS in decreasing the pain severity. All other parameters did not present a difference between the groups. Another study by Chao et al. (7) examined the effects of manual pressure release alone $(n=15)$ or in combination with KT $(n=16)$. They showed that pain reduced significantly immediately after treatment in both groups. However, combination therapy has a greater effect on muscle stiffness and contraction amplitude.

MPS may cause prolonged morbidity and significant deterioration in QOL. It has been suggested that new therapeutic approaches should include QOL measures to demonstrate that in addition to improvements in pain and disability, they provide significant positive effects in patients' lives. Indeed, previous studies evaluating the effects of other treatment options for neck and upper-back myofascial pain have included QOL questionairres, most commonly Nottingam Health Profile or SF-36, as an outcome variable (3). Nevertheless, previous studies investigating the effects of KT in patients with cervical MPS did not assessed the patients' QOL (7-10).

In the present study, we applied KT by inhibition tecnique at 5-day intervals for 20 days and found that in both groups there were a statistically significant decrease in pain severity and increase in PPT following intervention. Unfortunately, no significant differences in favour of therapeutic KT group were determined. Furthermore, we used SF-36 questionairre as an outcome measure and found that the participants' QOL showed significant and comparible improvement in both groups. Both groups showed sustained improvement at follow-up visit which was performed 1 month after treatment. The improvement seen in sham KT group may be due to the plasebo effect. Visual input of different color and the sensation on the skin may lead to a positive expenctancy and make the patients feel more confident (12). Moreover, sham KT probably provided sensory feedback provided sensory feedback which may improve the patients' adherence to the ergonomic principles by increasing their awareness (8). Last but not least, the beneficial effects observed in both groups may be related to the exercise program performed by all patients. Recently, a systematic review it has been reported that exercise has positive mild to moderate effects on pain intensity at short-term followup in patients with MPS (14). As a limitation of this study, there were no control group performing only exercise which could be compared to to therapeutic and sham KT groups.

\section{Conclusion}

KT combined with home-based exercise program decreases pain severity and improves QOL in patients who have an active trigger point in the upper trapezius muscle. However, similar improvements were also determined in sham KT group which can be attributed to placebo effect and/or beneficial effects of exercise therapy. As it is a non-invasive, economic and welltolerated method, KT combined with exercise can be applied for the treatment of MPS.

\section{Ethics}

Ethics Committee Approval: The study protocol was approved by the Hacettepe University Non-Invasive Clinical Research Ethics Committee (decision no: GO 15/158-08, date: 18.03.2015).

Informed Consent: All the participants signed a written informed consent form.

Peer-review: Externally peer-reviewed.

\section{Authorship Contributions}

Surgical and Medical Practices: S.Z., P.B., Concept: O.Ö., S.Z., Design: O.Ö., P.B., S.Z., Data Collection or Processing: S.Z., Analysis or Interpretation: S.Z., S.K., Literature Search: O.Ö., Writing: O.Ö., S.K.

Conflict of Interest: No conflict of interest was declared by the authors.

Financial Disclosure: The authors declared that this study has received no financial support.

\section{References}

1. Gerwin RD. Diagnosis of myofascial pain syndrome. Phys Med Rehabil Clin N Am 2015;25:341-55.

2. Saxena A, Chansoria M, Tomar G, Kumar A. Myofascial pain syndrome: an overview. J Pain Palliat Care Pharmacother 2015;29:16-21.

3. Celiker R, Atalay A, Guven Z. Health-related quality of life in patients with myofascial pain syndrome. Curr Pain Headache Rep 2010;14:361-6

4. Borg-Stein J, laccarino MA. Myofascial pain syndrome treatments. Phys Med Rehabil Clin N Am 2014;25:357-74.

5. García-Muro F, Rodríguez-Fernández AL, Herrero-de-Lucas A. Treatment of myofascial pain in the shoulder with Kinesio taping. A case report. Man Ther 2010;15:292-5.

6. Hashemirad F, Karimi N, Keshavarz R. The effect of Kinesio taping technique on trigger points of the piriformis muscle. J Bodyw Mov Ther 2016;20:807-14.

7. Chao YW, Lin JJ, Yang JL, Wang WT. Kinesio taping and manual pressure release: Short-term effects in subjects with myofasical trigger point. J Hand Ther 2016;29:23-9.

8. Öztürk G, Külcü DG, Mesci N, Şilte AD, Aydog E. Efficacy of kinesio tape application on pain and muscle strength in patients with myofascial pain syndrome: a placebo-controlled trial. J Phys Ther Sci 2016;28:1074-9.

9. Ay S, Konak HE, Evcik D, Kibar S. The effectiveness of Kinesio Taping on pain and disability in cervical myofascial pain syndrome. Rev Bras Reumatol Engl Ed 2017;57:93-9.

10. Azatcam G, Atalay NS, Akkaya N, Sahin F, Aksoy S, Zincir O, et al. Comparison of effectiveness of Transcutaneous Electrical Nerve Stimulation and Kinesio Taping added to exercises in patients with myofascial pain syndrome. I Back Musculoskelet Rehabil 2017;30:291-8

11. Koçyiğit H, Aydemir Ö, Fişek G, Ölmez N, Memiş AK. Form-36 (KF-36)'nın Türkçe versiyonunun güvenilirliği ve geçerliliği. İlaç ve Tedavi Dergisi 1999;12:102-6.

12. Wu WT, Hong CZ, Chou LW. The Kinesio Taping Method for Myofascial Pain Control. Evid Based Complement Alternat Med 2015;2015:950519.

13. Shah JP, Danoff JV, Desai MJ, Parikh S, Nakamura LY, Phillips TM, et al. Biochemicals associated with pain and inflammation are elevated in sites near to and remote from active myofascial trigger points. Arch Phys Med Rehabil 2008;89:16-23.

14. Mata Diz JB, de Souza JR, Leopoldino AA, Oliveira VC. Exercise, especially combined stretching and strengthening exercise, reduces myofascial pain: a systematic review. J Physiother 2017;63:17-22. 